DOI 10.31558/2519-2949.2021.1.17

УДК: $321.7: 323.2$

ORCID ID: https://orcid.org/ 0000-0002-7636-9088

Хлівнюк Т. П., Одеський національний університет імені І. І. Мечникова

\title{
«ВІКНА МОЖЛИВОСТЕЙ» ДЕРЖАВ В УМОВАХ ГЛОБАЛЬНОЇ ПАНДЕМІЇ COVID-19
}

Глобальна пандемія COVID-19 наочно продемонструвала усі «больові точки» краӥн, незважаючи на тип державного устрою та ступень сочіально-економічного розвитку. Визначено, шо економіки більшості крайн уже увійшли в глибоку рецесію, зростають показники держсавного боргу. Відсутні перспективи очікуваного зростання на найближчі роки, яке вже намітилося після глобальної фінансової кризи 2008 року, але у теперішный час прогрес останнього десятиліття для виходу з фінансової кризи є знівельований, у зв'язку з подіями, пов'язаними з COVID-19 та його глобальними наслідками у соиіально-політичній сфері будь-якої держави. Країни та регіони розробляють нові стратегії соиіальної політики, тактики та стратегії подальшого розвитку, адаптивні до вимог часу, наприклад, на рівні СС було озвучено потребу навіть нового «Плану Маршалла».

Не менш важсливим є і питання стану психічного здоров'я людини, погіршення якого пов'язане з соціальною ізолячією, дистанціюванням, а порою $і$ з втратою робочого місия, що, безумовно, деструктивно впливає на людину і потребує посилення уваги державних інституцій до иуих важливих питань.

Очікуваною є нова хвиля популізму, породжена піднесенням економічної нерівності на тлі наслідків пандемії, ще наочно і продемонструвала більшість краӥн світу.

С всі підстави вважати, що глобальна пандемія COVID-19 стала визначальним чинником суспільно-політичного життя та соиіальних взаємодій. Отже, можна стверджувати, що глобальна пандемія COVID-19 відкрила «вікна можливостей» у світовому політичному просторі, в якому державі в залежності від рівня розвитку демократії, соціальності та правотворчості приймають ті чи інші рімення щодо обмеження певних прав населення, що має як позитивні, так $i$ негативні наслідки.

Отже, «вікна можсливостей» у період глобальної пандемії розкрили всі «Ахіллесові п'яти» держав, продемонструвавши їх можливості / неможливості знайти адекватні події-відповіді на складні виклики часу світового масштабу, що иілком залежало від розвиненості країни в цілому, ії важливого атрибуту громадянського суспільства, вектору спрямованості державної політики, інструментів здійснення контролю за владою, спрямованістю визначати завдання першочергового значення і можсливістю держав завищити своӥх громадян від иих викликів,

Ключові слова: глобальна пандемія, громадянське суспільство, виклики часу, подї-відповіді, «вікна можливостей».

Кінець 20-х років змінив світ настільки різко, що навіть світові економічні кризи минулого століття і першого десятиліття XXI ст. (2008 р.) не мали «таких шокованих результатів і наслідків. Глобальна пандемія COVID-19 наочно продемонструвала усі «больові точки» країн, незважаючи на тип державного устрою та ступень соціально-економічного розвитку.

Глобальна пандемія коронавірусної інфекції- це не лише показники захворюваності та смертності, а й уповільнення глобальної економіки, і як наслідок - зростання безробіття, проблеми продовольчої забезпеченості, а також багатьох інших негараздів. Економіки більшості країн уже увійшли в глибоку рецесію, зростають показники державного боргу. Відсутні перспективи очікуваного зростання на найближчі роки, яке вже намітилося після глобальної фінансової кризи 2008 року, але нині прогрес останнього десятиліття для виходу з фінансової кризи є знівельований [1].

Країни та регіони розробляють нові стратегії соціальної політики, тактики та стратегії подальшого розвитку, адаптивні до вимог часу, наприклад, на рівні ЄС було озвучено навіть потребу нового «Плану Маршалла» [2]. 
Дійсно, саме ця проблема стала пріоритетною в минулому році і визначила низку глобальних питань. Насамперед, це змінені підходи до соціального захисту населення з урахуванням не миттєвого завершення початої епідемії. Будь-які зміни у соціально-економічній сфері не можуть не торкнутися і політичних змін, пов'язаних, перш за все, з правовими межами. Так, впровадження систем відстеження та моніторингу розповсюдження хвороби, порядку перетину державних кордонів, рівень обмежень права на мирні збори та інші зібрання людей тощо - $є$ певною мірою обмеження прав i свобод людини з метою захисту ії здоров'я і навіть життя. У той же час ці обмеження можуть бути і змаганнями наступу на ліберально-демократичні цінності та їх подальшим обмеженням чи пристосуванням до сучасних світових реалій. I це один бік світової глобальної проблеми. 3 іншого боку - це необхідність радикальної зміни вектору діяльності влади, яка у нових умовах повинна забезпечити якнайбільшу стійкість державних фінансів, щоб уряди могли якісно надавати державні послуги та адекватно реагувати на проблеми в національних системах охорони здоров'я.

Не менш важливим $€$ і питання стану психічного здоров'я людини, погіршення якого пов'язане з соціальною ізоляцією, дистанціюванням, а порою і з втратою робочого місця, що, безумовно, деструктивно впливає на людину і потребує посилення уваги державних інституцій .до цих важливих питань.

Проблемою є максимальна відповідність чинних урядових соціальних програм принципу справедливості з метою підтримки тих соціальних груп, які опинилися чи потенційно можуть опинитися в стані соціальної дезадаптації, потребують соціальної реабілітації тощо. Очевидно, що в цих умовах національним урядам доведеться інвестувати в різноманітні експериментальні технології, які можуть і не принести очікуваного результату.

Світова сучасна криза, пов'язана з епідемією, стала викликом і для політичних лідерів, урядів, одні з яких зміцнюють свій авторитет завдяки результативним соціально-економічним ініціативам, а інші - ще більше поглиблюють недовіру до себе.

Цілком зрозуміло, що якщо проблеми, породжені пандемією COVID-19, не вирішувати належно через соціальну, економічну та ін. політику, то висхідна соціальна криза збільшить нерівність, виключення, дискримінацію та глобальне безробіття у середньо- та довгостроковій перспективі. Не викликає ніяких сумнівів необхідність додаткових інструментів політики щодо подолання очікуваних негативних наслідків від кризи. Найперше, ці інструменти мають мінімізувати негативний вплив карантинних обмежень на зайнятість та бідність, а також модернізувати систему охорони здоров'я, адаптовану до нових викликів і загроз. Очевидно, що ця криза стане вагомим чинником подальшого поглиблення кризового стану та зміни моделі інституту соціальної держави [3].

Незважаючи на те, що майже всі держави з початком розповсюдження коронавірусної інфекції розпочали розробку та реалізацію програм, які мали б стати ефективною відповіддю на ці виклики, все ж у багатьох випадках пропоновані заходи були популістськими - відповідь на поточні очікування громадян. На практиці навіть у високорозвинених державах виникли складності впровадити ініційовані пакети соціально-економічного порятунку. Окрім цього, динамічно змінювана ситуація з показниками інфікованості постійно актуалізує нові проблеми, які потребують оперативного реагування найперше інститутів держави.

Безумовно, пандемія COVID-19 стала викликом для держав, зокрема й високорозвинених, та показала низку проблем у соціальній сфері, освіті, охороні здоров'я та інших сферах життєдіяльності. Криза, зумовлена коронавірусною інфекцією, зактуалізувала проблему нерівності та несправедливості, які загрожують добробуту, безпеці та життю людей.

Є всі підстави для ствердження, що глобальна пандемія COVID-19 стала визначальним чинником суспільно-політичного життя та соціальних взаємодій. Загроза інфікування населення змінила стиль життя людей, впровадила обмеження та соціальне дистанціювання тощо. Нового звучання набула цінність солідарності щодо обмежень одних громадян (молодих і здорових) для захисту уразливих категорій (літнього віку, з хронічними недугами).

На тлі викликів, зумовлених карантинними обмеженнями, наростає відчуття безсилля урядів справитися з висхідною кількістю проблем у сферах охорони здоров'я, освіти, зайнятості населення, підтримки малого бізнесу та ін. Це, своєю чергою, позначається на рівневі довіри громадськості до інститутів політики, особливо владних а́кторів. Очевидно, що економічні проблеми, які поглибилися на тлі карантинних обмежень, посилять культурні та інші соціальні розриви; радикалізують політику, що відтак зумовить чергове піднесення популістів, консервативнонаціоналістичних та інших радикальних політичних а́кторів; активізується протестна «сила вулиці» [4] тощо. 
Упродовж карантину уряди змінюють стратегії від значних соціальних обмежень до більш помірних обмежувальних заходів, які мають відповідати інтересам держав та суспільств з урахуванням епідеміологічної ситуації. Соціальна політика конструюється з розумінням того, що нинішня коронавірусно-карантинна криза не $\epsilon$ короткочасною та матиме хвилеподібний характер. Очевидно, що пандемія COVID-19 прискорить уже наявні тенденції висхідного націоналістичного популізму, неоавторитаризму, дефектів ліберальної демократії тощо [5]. Ймовірним є ще більше посилення розбіжностей між державами. Не виключеним $є$ деякий відступ від глобалізації (найперше економічної) через появу нових бар'єрів для міжнародної торгівлі, інвестування, туризму. Уряди, особливо держав недемократичних або ж тих, у яких стрімко погіршується якість демократії, набувають щораз більше повноважень для відстеження та моніторингу життя населення. Можна спрогнозувати, що світ на «постковідному» етапі може стати менш вільним, менш конкурентоспроможним, аніж та його перспективна модель, яка прогнозувалася нещодавно. Соціальна ж політика стане однією з тих, які мають найперше адаптуватися до потенційних новітніх ризиків різного кшталту.

У теперішній час можна стверджувати, що немає держав, які б не вважали себе соціальними, тобто безпосередньо пов'язаними із закріпленням на конституційному рівні соціальних прав людини. Соціальні права, у свою чергу, по'вязані із соціальними відносинами людини, із суспільством, із державою тощо. У цілому соціальні права стосуються задоволення таких потреб, які б давали змогу підтримувати життя соціуму, забезпечували людині гідний життєвий рівень, право на працю та винагороду за неї, на житло, тощо. Забезпечення соціальних прав пов'язують із солідарністю, яка має статус найголовнішій фундаментальній цінності, наданий Декларацією тисячоліття ООН та Хартією основних прав Європейського союзу. Отже, здійсненність таких прав $€$ визначальною рисою жодної сучасної держави

Виходячи з вищезазначеного, варто звернути увагу на те, що кінець XX - початок XXI ст. чітко висвітлив такі соціальні проблеми, як зростаючий розрив між елітою та малозабезпеченими масова низхідна мобільність середнього класу, втрата почуття соціальної захищеності [6]. Отже, всі ці серйозні проблеми сучасності набули нового значення і потужної сили під впливом глобальної пандемії COVID-19.

Очікуваною є нова хвиля популізму, породжена піднесенням економічної нерівності на тлі наслідків пандемії [7]. Вочевидь, ця хвиля буде сильнішою, позаяк і економічні наслідки будуть руйнівніші за ті, які стали результатом глобальної фінансової кризи 2008 року. Поточна криза очікувано принесе значно вищий рівень збіднення більшості населення планети. Результати вже перших виборчих кампаній, проведених в умовах карантинних обмежень, засвідчують розвиток такої деструктивної тенденції. Наведемо приклади. У Сербії на парламентських виборах 21.06 .2020 р. перемогу з великим приростом голосів здобула популістська, консервативно-націоналістична Сербська прогресивна партія (SNS). У Хорватії на виборах парламенту 05.07.2020 р. найбільше голосів набрав консервативно- націоналістичний, правоцентристський Християнський демократичний союз (HDZ); у складі цієї партії історично наявні як помірковані, так і екстремістські фракції, які радикалізують хорватську політику.

Існує серйозний ризик того, що на тлі протестів проти затяжних карантинних обмежень виникатимуть щораз нові протестні рухи, які своєю чергою стрімко інституціоналізуватимуться та пройдуть до парламентів, як це уже було в випадках іспанської партії «Podemos», італійської партії «Movimento 5 Stelle» та ін. Така гіпотеза грунтується на аналізі наслідків глобальної фінансової кризи, яка розпочалася у 2008 році та мала серед своїх наслідків появу громадянських рухів на взірець «Occupy Wall Street» (2011 р., США) [8], «Indignados» (2011-2012 рр., Іспанія) та ін. Дедалі частіше звучать гасла на взірець «Ми - 99\%» (We are the $99 \%$ ), обгрунтовується ідея доцільності впровадження безумовного базового доходу тощо.

Таким чином, зазначені проблеми значно вплинули та обгрунтували зміну форм протесту замість звичних транспарантів під час вуличних акцій- популярні комп'ютерні ігри, замість натовпів - автомобільні гудки, написи на масках тощо. Це приклад того, що новітні проблеми потребують новітніх підходів до розв'язання. Прикладами $€$ цифрові страйки, на зразок ініційованих екоактивістами Г. Тунберг та ін. (\#digitalstrike). Американський молодіжний політичний рух «Sunrise Movement» як альтернативу масовим зібранням використав телефонні дзвінки та листи для роз'яснення необхідності нового політичного курсу «Green New Deal» з метою збалансування економіки в умовах викликів сучасності.

У даному контексті важливо звернути увагу на таке поняття як «вікно можливостей». Як відомо, це складова моделі порядку денного політики американського ученого Д, Кінгдона, за якою у межах 
політико-управлінського процесу виокремлені такі його складові, як «потік проблеми», тобто показники значущості проблеми, що надають їй публічного характеру, роблять їі видимою для «виробників політики»; «потік розроблення проблеми», тобто можливих політичних рішень чи альтернатив, розроблених тими, хто зацікавлений у цих рішеннях; «потік політичних взаємовідносин», тобто політичні події у вигляді виборів, демонстрації різного рівня, соціальні заворушення тощо, у результаті яких можлива навіть зміна уряду, які організовані групами інтересів. За Кінгдоном, у критичні моменти зазначені потоки можуть 3'єднатися, і саме тоді і відкриваються так звані «вікна можливостей», тобто той час, коли певна проблема становиться найголовнішою і стає предметом необхідності прийняття політичного рішення [9].

Інші американський вчений Д. Овертон розуміє поняття «вікна можливостей» як «межу тих ідей, які можуть бути сприйняти суспільством у будь-який конкретний момент» [Цит. за: 9]. Інакше кажучи, це певні політичні ідеї, які підтримані громадською думкою, вже не сприймаються як радикальні і очікуються суспільством у якості політичних рішень. Зі зміною громадської думки відбувається зрушення «вікон можливостей».

Отже, можна стверджувати, що глобальна пандемія COVID-19 відкрила «вікна можливостей» у світовому політичному просторі, в якому державі в залежності від рівня розвитку демократії, соціальності та правотворчості приймають ті чи інші рішення щодо обмеження певних прав населення, що має як позитивні, так і негативні наслідки.

Пандемія 2020 року лише прискорила розвиток широкого спектра новітніх соціальних ініціатив. Так, наведемо відомі приклади онлайн-подій непокори під час пандемії COVID-19. Так, вже другий рік поспіль, від 31.03.2019 р., у Гонконгу проходять антикитайські протести, спрямовані проти законопроєкту про екстрадицію підозрюваних у порушенні закону осіб до материкового КНР. Власне нові правові норми потенційно могли б бути використані для передачі в руки китайського правосуддя дисидентів і несправедливо переслідуваних людей. Від середини січня 2020 року акції протесту почали набувати віртуалізованого формату. Наприклад, онлайн-гра «Animal Crossing: New Horizons» стала майданчиком для акцій та протестів на підтримку свободи Гонконгу. Також активно почав використовуватися автономний месенджер «Bridgefy», що дозволяє анонімно й децентралізовано спілкуватись, виключаючи можливість стеження за учасниками розмов.

Прикладом онлайн-демонстрацій $є$ й акції міжнародного кліматичного руху «Fridays for Future» [10]. Зокрема, у Німеччині онлайн-демонстрація модерувалася з відкритого простору перед будівлею Рейхстагу в Берліні (24.04.2020р.). У ході цієї акції на траві було викладено близько 10 тисяч транспарантів і банерів, які традиційно несуть демонстранти [11]. Окрім цього, щоп'ятниці в Інтернеті, на основних соціальних медіа, проводиться обговорення екологічних проблем. Для цього використовується Instagram (https://www.instagram.com/fff.digital/), Twitter (https://twitter.com/fff_digital), Facebook (https://www.facebook.com/fffdigital/), YouTobe (https://www.youtube.com/channel/UChRvsurw_ 0qeaPgGP2ff7hA) тощо [12].

Можна навести і приклади акції опозиції на захист демократії в Ізраїлі проти уряду Б. Нетаньягу (19.04.2020р.), у Російській Федерації, основна частина протестів в якій у період карантину пройшла в онлайн-форматі (віртуальні мітинги). Використовувалася функція «Розмови» в мобільній версії «Yandex.Maps» $\mathrm{i}$ «Yandex.Navigator» та ін.

В Україні першим онлайн-мітингом стала проведена 27.03.2020 р. на платформі Zoom акція «Hi знищенню культури!» проти скорочення фінансування у сфері культури. Усі охочі з плакатами могли доєднатися до протесту проти планів Міністерства фінансів України скоротити державне фінансування культури у зв’язку з пандемією коронавірусу.

Отже, «вікна можливостей» у період глобальної пандемії розкрили всі «Ахіллесові п’яти» держав, продемонструвавши їх можливості/неможливості знайти адекватні події-відповіді на складні виклики часу світового масштабу, що цілком залежало від розвиненості країни в цілому, їі важливого атрибуту громадянського суспільства, вектору спрямованості державної політики, інструментів здійснення контролю за владою, спрямованістю визначати завдання першочергового значення і можливістю держав завищити своїх громадян від цих викликів,

\section{Бібліографічний список:}

1. Хлівнюк Т. П. Зміна завдань соціальної політики на тлі викликів глобальної пандемії COVID-19. Міжнародна спільнота в умовах змін: багатовимірний підхід: колективна монографія. Т. 4 / за ред. О. Кордонської, Р. Кордонського. Ольштин - Львів: Інститут політичних наук Вармінсько-Мазурського університету в м. Ольштин (Польща), 2020. С. 191-202.

2. COVID-19: How to Get Tested, https://www.dhs.wisconsin.gov/covid-19/testing.htm, [17.08.2020]. Dixon R., No lockdown here: Belarus's strongman rejects coronavirus risks. He suggests saunas and vodka, «The Washington Post» 2020, 27 Mar. 
3. Legrain P. A COVID-19 Marshall Plan for Europe. URL: https://www.project-syndicate.org/commentary/ european-union-covid-marshall-plan-by-philippe-legrain-2020-04?barrier=accesspaylog, [10.04.2020].

4. Хлівнюк Т. П Соціальний вплив COVID-19: видозміна громадсько-політичного активізму. Міжнародна спільнота в умовах змін: багатовимірний підхід:колективна монографія. Т. 2 / за ред. О. Кордонської, Р. Кордонського. Ольштин - Львів: Інститут політичних наук Вармінсько-Мазурського університету в м. Ольштин (Польща), 2020. С. 10-20.

5. Della Porta D., Fernández J., Kouki H., Mosca L. Movement Parties Against Austerity, Cambridge 2017.

6. Хома Н. М. Моделі соціальної держави: світовий та український досвід: монографія. Київ: Видавництво «Юридична думка», 2012. С. 397

7. Cohen N. Beware a new wave of populism, born out of coronavirus-induced economic inequity, «The Guardian». 2020, 18 Apr.

8. Gould-Wartofsky M. A. The Occupiers: The Making of the 99 Percent Movement, New York, 2015.

9. Семигіна Т. Вікна можливостей. Новітня політична лексика (неологізми, оказіоналізми та інші новотворення. Енцииклопедичний словник-довідник. За заг. ред. Н. М. Хоми. Львів: «Новий Світ - 2000», 2015. C. 54.

10. Global digital strike, https://fridaysforfuture.org/next-big-strike-april-24/, [18.03.2020].

11. Van der Wolf M. Economic, Environmental Interests Compete in a Post-COVID Europe, https://www.voanews.com/ covid-19-pandemic/economic-environmental-interests-compete-post-covid-europe, [12.08.2020].

12. Sharma G. Covid-19 is changing the way people protest around the world, https://www.trtworld.com/magazine/ covid-19-is-changing-the-way-people-protest-around-the-world-35229, [08.04.2020].

\section{References:}

1. Khlivnyuk T. P. Zmina zavdan' sotsial'noï politiki na tli viklikiv global'noï pandemiï COVID-19. Mizhnarodna spil'nota v umovakh zmin: bagatovimirnii pidkhid: kolektivna monografiya. T. 4 / za red. O. Kordons'koï, R. Kordons'kogo. Ol'shtin - L'viv: Institut politichnikh nauk Varmins'ko-Mazurs'kogo universitetu v m. Ol'shtin (Pol'shcha), 2020. C. 191-202 [In Ukraine].

2. COVID-19: How to Get Tested, https://www.dhs.wisconsin.gov/covid-19/testing.htm, [17.08.2020]. Dikhon R., No lockdown here: Belarus's strongman rejects coronavirus risks. He suggests saunas and vodka, «The Washington Post» 2020, 27 Mar. [In English].

3. Legrain R. A COVID-19 Marshall Plan for Europe. URL: https://www.project-syndicate.org/commentary/ european-union-covid-marshall-plan-by-philippe-legrain-2020-04?barrier=accesspaylog, [10.04.2020]. [In English].

4. Khlivnyuk T. P Sotsial'nii vpliv COVID-19: vidozmina gromads'ko-politichnogo aktivizmu.

Mizhnarodna spil'nota v umovakh zmin: bagatovimirnii pidkhid:kolektivna monografiya. T. 2 / za red. O. Kordons'koï, R. Kordons'kogo. Ol'shtin - L'viv: Institut politichnikh nauk Varmins'ko-Mazurs'kogo universitetu v m. Ol'shtin (Pol'shcha), 2020. S. 10-20. [In Ukraine].

5. Della Porta D., Fernández J., Kouki N., Mosca L. Movement Parties Against Austerity, Cambridge 2017. [In English].

6. Khoma N. M. Modeli sotsial'noï derzhavi: svitovii ta ukraïns'kii dosvid: monografiya. Kiïv: Vidavnitstvo «Yuridichna dumka», 2012. S. 397 [In Ukraine].

7. Cohen N. Beware a new wave of populism, born out of coronavirus-induced economic inequity, «The Guardian». 2020, 18 Apr. [In English].

8. Gould-Wartofsky M. A. The Occupiers: The Making of the 99 Percent Movement, New York, 2015. [In English].

9. Semigina T. Vikna mozhlivostei. Novitnya politichna leksika (neologizmi, okazionalizmi ta inshi novotvorennya. Entsiklopedichnii slovnik-dovidnik. Za zag. red. N. M. Khomi. L'viv: «Novii Svit - 2000», 2015. S. 54. [In Ukraine].

10. Global digital strike, https://fridaysforfuture.org/next-big-strike-april-24/, [18.03.2020]. [In English].

11. Van der Wolf M. Economic, Environmental Interests Compete in a Post-COVID Europe, https://www.voanews.com/ covid-19-pandemic/economic-environmental-interests-compete-post-covid-europe, [12.08.2020]. [In English].

12. Sharma G. Covid-19 is changing the way people protest around the world, https://www.trtworld.com/magazine/ covid-19-is-changing-the-way-people-protest-around-the-world-35229, [08.04.2020]. [In English].

\section{Khlivnyuk T. P. "Windows of opportunities» of states in the conditions of the COVID-19 global pandemic}

The global COVID-19 pandemic has clearly demonstrated all the "pain points» of countries, regardless of the type of government and the degree of socio-economic development. It is determined that the economies of most countries have already entered a deep recession, growing public debt. There are no prospects for the expected growth in the coming years, which has already emerged since the global 
financial crisis of 2008, but currently the progress of the last decade to overcome the financial crisis is offset, due to events related to COVID-19 and its global consequences in the socio-political sphere of any state. Countries and regions are developing new social policy strategies, tactics and strategies for further development that are adaptable to the demands of the times, for example, at the EU level the need for even a new «Marshall Plan» has been voiced.

Equally important is the issue of human mental health, the deterioration of which is associated with social isolation, distancing, and sometimes with job loss, which, of course, has a destructive effect on people and requires increased attention of state institutions to these important issues.

A new wave of populism is expected, caused by the rise of economic inequality against the background of the effects of the pandemic, which is clearly demonstrated by most countries.

There is every reason to believe that the global pandemic COVID-19 has become a determining factor in socio-political life and social interactions. Thus, it can be argued that the global pandemic COVID-19 has opened "windows of opportunity» in the global political space, in which the state, depending on the level of democracy, sociality and lawmaking, make certain decisions to restrict certain rights of the population. and negative consequences.

Thus, the «windows of opportunity» during the global pandemic opened all the "Achilles' heel» states, demonstrating their capabilities / inability to find adequate events-responses to the complex challenges of the world, which depended on the development of the country as a whole, its important civic attribute. society, the vector of direction of public policy, tools for exercising control over power, the focus on identifying priorities and the ability of states to overestimate their citizens from these challenges.

Keywords: global pandemic, civil society, challenges of time, response events, "windows of opportunity». 